\title{
Bir Dış Politika Aracı Olarak Turizm: Gana Örneği
}

\author{
Doç. Dr. Burhan AYDEMIR
}

Balıkesir Üniversitesi, Turizm Fakültesi, Balıkesir, e-posta: burhanaydemir@gmail.com

Kürşat BAL

Doktora Öğrencisi, Balıkesir Üniversitesi, Sosyal Bilimler Enstitüsü, Balıkesir, e-posta: kursatbal41@gmail.com

\section{Öz}

Bu çalışmada, dış politika ve turizm ilişkisi dikkate alınarak Türkiye'nin Afrika ülkeleri ile yaptığı turizm anlaşmaları incelenmiştir. Türkiye Afrika'daki ülkeler ile turizm dâhil çeşitli konularda anlaşma imzalamıştır. Ancak turizm istatistiklerine göre, Afrika'daki fakir ülkelerden Türkiye'ye az sayıda turist gelmektedir. Türkiye; ortak tarihi geçmişi olan Afrika ülkeleri ile ticari, siyasi, sosyal, kültürel, ekonomik ve turistik ilişkileri geliştirme çabasındadır. Gana ile ilişkilerimiz bu çerçevede değerlendirilmiştir. Nitel bir araştırma olan çalışmada veriler, doküman inceleme tekniği ile elde edilmiştir. Afrika'daki fakir ülkelerle imzalanan turizm anlaşmalarının aslında turistik ilişkilerin geliştirilmesinden çok, bu ülkelerle her alanda işbirliğinin artırılması için bir dış politika aracı olduğu yönündedir.

Anahtar Kelimeler: Dış politika, Turizm, Turizm antlaşması, Gana.

\section{Önerilen Atıf:}

Aydemir, B. ve Bal, K. (2018). Bir Dış Politika Aracı Olarak Turizm: Gana Örneği, Türk Turizm Araştırmaları Dergisi, Cilt.2, Sayı.1, ss.71-84. 


\title{
Tourism as a Foreign Policy Tool: The Case of Ghana
}

\author{
Associate Prof. Dr. Burhan AYDEMIR \\ Balıkesir University, Faculty of Tourism, Balıkesir, e-mail: burhanaydemir@gmail.com
}

Kürşat BAL

Ph.D. student, Balıkesir University, Balıkesir, e-mail kursatbal41@gmail.com

\begin{abstract}
In this study, Turkey's tourism agreements with African countries were examined by considering the relationship between foreign policy and tourism. Turkey has signed agreements with countries in Africa on various issues including tourism. According to tourism statistics, however, a small number of tourists come to Turkey from poor countries in Africa. Turkey is trying to develop commercial, political, social, cultural, economic and tourism relations associations with African countries that have a common historical background. Our relationship with Ghana has been evaluated in this framework. In this study, which is a qualitative research, data were obtained by using the document review technique. The result of the study is that the tourism agreements signed with African poor countries are actually a foreign policy tool for the enhancement of cooperation with these countries in every field, rather than the development of tourism relations.
\end{abstract}

Keywords: Foreign policy, Tourism, Tourism agreement, Ghana.

\section{Suggested Citation:}

Aydemir, B. and Bal, K. (2018). Tourism as a Foreign Policy Tool: The Case of Ghana, Journal of Turkish Tourism Research, Vol.2, Issue.1, pp. 71-84. 


\section{Gíriş}

Bir devletin sınırları dışındaki ülkelere uyguladığı siyaset, dış politika olarak tanımlanmaktadır. Ülkenin bulunduğu coğrafya, dünya konjonktüründeki gelişmeler, karizmatik liderler, tehdit algılamaları, ittifaklar, ülkenin ekonomik ve askeri gücü dış politikayı belirleyen önemli unsurlardır (Criss, 2002).

Dış ülkelere yapılan bir turistik seyahat, gezmek ve görmek yanında ülkeler arasında kültürel, sosyal, ekonomik ve toplumsal iletişimi de sağlamaktadır. Turizm; içinde bulunduğumuz yıllarda Türk dış politikasının önemli araçlarından birisi haline gelmiştir. Turizm; "yumuşak güç" olarak adlandırılan bir dış politika aracı olarak değerlendirilmektedir. Tarih, kültürel değerler, toplumsal özellikler, eğitim, gelenekler vb. kullanılarak karşı devletin dış politika tercihlerini etkileme, "yumuşak güç" olarak tanımlanmaktadır (Akbaş ve Tuna, 2012). Literatür çalışmasının alt başlıkları şöyledir: "Uluslararası ilişkiler, Dış Politika ve Turizm", "Uluslararası Anlaşmalar ve Turizm Anlaşmaları" ve "Türkiye'nin Genel Dış ve Afrika Politikası".

\section{ULUSLARARASI İLIŞKILER, DIŞ POLİTIKA ve TURIZM}

Arı'ya (2008) göre uluslararası ilişkiler; sadece devletlerarasında değil, ülke sınırlarını aşan ve hükümetler, halklar, uluslararası kuruluşlar, sivil toplum kuruluşları ve devlet dışı kuruluşlar arasındaki siyasal, sosyal, turistik, kültürel, ekonomik, sportif, dini, ticari, tüm ilişkileri içine alan bir kavram olarak kullanılmaya başlanmıştır. Uluslararası ilişkilere yön veren temel değişken güçtür. Bir devletin sahip olduğu unsurlar (savaş gücü, ithalatı sınırlama, ambargo) ve şartlar (nüfus ve toprağının büyüklüğü, ekonomik gücü, iktisadi kalkınma düzeyi, teknolojisi, vb) gücün en önemli unsurları arasında sayılabilir. Ekonomik ilişkiler, uluslararası ilişkilerin en önemli bir bölümünü oluşturur. Ekonomi, politikanın ayrılmaz bir parçasıdır. Uluslararası ilişkilerde gücün kullanılmasında, ekonomik koşullar çok önemlidir. Gücün kullanılmasında çok çeşitli yollar izlenebilir. Bunların hangisinin kullanılacağını belirleyen, içinde bulunulan şartlar ve muhatabin durumudur.

Arı'ya (2008) göre dış politika; uluslararası siyasi sorunları, bir devletin ya da devletlerin amaçları, hedefleri ve davranışları açısından değerlendirir ve bir devletin uluslararası sisteme veya diğer devletlere karşı tutumunu inceler.

Kürkçüoğlu (1980); bir devletin başka bir devlete veya devletlere karşı izlediği politikayı dış politika olarak tanımlar. Bu politikalarla başta siyasi, ekonomik, hukuki, turistik, dini, sportif, kültürel ilişkiler olmak üzere her çeşit ilişkilerin yönlendirilmesine çalışlır. Bir ülke ile ticari ilişkiler, hibe şeklinde dış yardımlar, dış borç verme, tek taraflı yardımlar, siyaseten destekleme, askeri yardımlar, eğitim yardımları, iktisadi işbirliği politikaları (serbest ticaret bölgesi, tercihli ticaret anlaşmaları, gümrük birliği, vb), ambargo, dini ve dilsel ilişkiler, sportif, kültürel ve turistik ilişkiler bunlar arasında sayılabilir. Milli para ile alışveriş, vize uygulamama, pasaportsuz geçiş, uzun süre diğer ülkede kalma imkânı vb. uygulamalar ülkeler arasındaki ilişkileri güçlendirmektedir.

Turizm; özellikle ikinci dünya savaşı sonrasında tüm dünyada hızla gelişen bir sektördür. Dünyanın birçok ülkesi özellikle gelişmekte olan ülkeler döviz geliri elde etmek için dış turizme önem vermektedir. Turizmin çeşitli tanımları yapılmıştır. Bir tanıma göre turizm; kişilerin sürekli yaşadıkları yer ve çevre dışına çeşitli amaçlarla yaptıkları, en az 24 saat veya bir 
gecelemeden oluşan, ticari amaç güdülmeyen, geçici seyahat ve konaklamaların ortaya çıkardığı ekonomik ve sosyal nitelikli tüketim olayı ve ilişkilerin bütünüdür (Usta, 2014). Turizm toplumları bir araya getirmekte, böylelikle kişilerin birbirlerini tanımaları ve birbirileri hakkındaki önyargıların ortadan kalkmasına yol açmaktadır. Uluslararası turizm talebine etki eden faktörleri; ekonomik faktörler, sosyal faktörler, politik ve yasal faktörler, psikolojik faktörler ve diğer faktörler olarak belirlemek mümkündür.

Türkiye, turist sayısı açısından dünyada 6'ncı, turizm gelirleri açısından ise 12'nci sıradadır. Turist girişleri açısından Türkiye uluslararası turizm pazarından \% 3,5, Avrupa turizm pazarından \% 6,9 pay almıştır. Turizm gelirlerinde ise bu pay sırasıyla \% 2,7 ve \% 6,7 olarak gerçekleşmiştir (www.ktbyatirimisletmeler.gov.tr, UNWTO 2015).

Turizm ve dış politika birbirini karşılıklı olarak etkilemektedir. Bunlar;

- Devletin yönetim sisteminin ekonomi politikası ve turizm politikası üzerinde etkileri,

- Politik seyahat ve toplantıların turizme olan etkileri,

- Politik olayların turizm üzerindeki olumlu veya olumsuz etkileri,

- Uluslararası politikaların turizme olan etkileri, olarak ele alınabilir.

Turistik ilişkiler, ulusları birbirine daha çok yaklaştırmakta ve böylece evrensel barışın oluşumuna katkı sağlamaktadır. Günümüzde turizm, uluslararası barış ve dostluğun temel öğelerinden biri olarak kabul edilmektedir (Usta, 2014).

Türkiye Cumhuriyeti Başbakanı Sayın Ahmet Davutoğlu'nun 25 Kasım 2015 tarihinde ve Sayın Binali Yıldırım'ın 24 Mayıs 2016 tarihinde Türkiye Büyük Millet Meclisine sundukları 64. ve 65. Hükümet Programlarında turizmle ilgili olarak şu ifadeler yer almıştır. "AK Parti hükümetleri olarak turizme sadece turist sayısı ve gelir odaklı bakmadık. Etkili bir turizm politikasının, ekonominin yanı sıra dış politika ve kültür alışverişi sayesinde oluşturulacak pek çok kazanım sağlayacağının bilinciyle hareket ediyoruz" (www.basbakanlik.gov.tr). Başbakan Sayın Davutoğlu ve Sayın Yıldırım tarafından yapılan konuşmalarda, turizmin ekonomik faydalar yanında bir dış politika aracı olarak kullanılacağı açıkça belirtilmiştir. Ancak yine AK Parti hükümetleri olan 60., 61., 62. ve 63. Hükümet Programlarında bu ifadeler yer almamıştır.

\section{ULUSLARARASI ANLAŞMALAR ve TURİZM ANLAŞMALARI}

Uluslararası anlaşmalar; iki veya daha fazla devlet tarafından akdedilmiş olan ve Türkiye'de Cumhurbaşkanının onayıyla Resmî Gazetede yayımlanarak yürürlüğe konulan ve Türk normlar hiyerarşisinde kural olarak kanun değerinde bulunan bağlayıcı hukuk kurallarıdır (Gözler, 2007).

Milletlerarası anlaşmalarla ilgili hüküm, Anayasa'nın 90. Maddesinde düzenlenmiştir. Türkiye Cumhuriyeti Hükümetleri çeşitli ülkelerle birçok konuda anlaşma imzalamaktadır. Bu anlaşmalardan bir tanesi de turizm anlaşmalarıdır. İkili turizm anlaşmalarının temel amacı, turizm konusunda karşılıklı olarak ilişkileri ve işbirliğini geliştirmek ve ülkemize gelecek turist sayısının artmasını sağlamaktır. Anlaşma imzalanan ülkeler incelendiğinde bazı ülkelerden ülkemize gelen turist sayısının arttığı görülmektedir. 
Türkiye'nin uluslararası alanda diğer ülkelerle yaptığı Turizm İşbirliği Antlaşmalarının çoğunda bu antlaşmanın; 1963'te Roma'da toplanan Birleşmiş Milletler Turizm ve Uluslararası Seyahat Konferansı tavsiye kararları, 1 Ağustos 1975 tarihinde Helsinki'de imzalanan Avrupa İşbirliği ve Güvenlik Konferansı Nihai Belgesi Hükümleri içinde yer verilen turizmle ilgili kararlar, Ekim 1980'de Dünya Turizm Örgütü tarafından kabul edilmiş Manila Deklarasyonu, 1982 Acapulco Deklarasyonu, 1989 Hague Turizm Deklarasyonu ve 3-4 Kasım 1994 Osaka Turizm Bildirisi'nin ruhuna uygun olarak yapıldığı belirtilmektedir (www.resmigazete.gov.tr).

Türkiye 1960'lı yıllarda uluslararası iktisadi işbirlikleri ve antlaşmaları çerçevesinde ilk turizm işbirliği anlaşmasını, 1964 yılının ekim ayında Bulgaristan'la Sofya'da yaptı. Bu anlaşmayı 1965 yılında Yugoslavya, 1966 yılında ise Ürdün ve Irak ile yapılan anlaşmalar izledi. 1968 yılında da Mısır ve Lübnan ile ikili işbirliği çerçevesi çizildi. 1964 yılından 1980 yılına kadar yukarıda sayılanların dışında Balkan ülkeleri, Yunanistan, Cezayir ve Almanya olmak üzere dört anlaşma daha gerçekleşmiştir (www.tursab.org.tr).

\section{TÜRKİYE'NİN GENEL DIŞ VE AFRİKA POLITTIKASI}

Dış İşleri Bakanlığı, Türkiye'nin dış politikasını genel hatlarıyla şu şekilde değerlendirmektedir: "Ülkemizin küresel rekabette ön plana çıkabilmesi yakın coğrafyaların ötesinde varlık göstermesine bağlıdır" (www.mfa.gov.tr/2016).

"Küresel gelişmeler doğrultusunda, geçmişte uzak coğrafyalar olarak nitelendirilen bölgelerde ülkemiz için yeni ortaklar ve iş çevrelerimiz için yeni pazarlar ile yatırım olanaklarının tespitine ve buna uygun siyasi ilişkiler ağının tesis edilmesine yönelik faaliyetler ilgili tüm kurum ve kuruluşların katkısıyla sürdürülecektir" (www.mfa.gov.tr/2016).

Dış İşleri Bakanlığı kaynakları, Afrika ile ilişkileri şöyle ele almaktadır: "Çok boyutlu dış politikamızın stratejik faaliyet alanlarından birini Afrika kıtasıyla ilişkilerimiz oluşturmaktadır. Uluslararası siyaset ve ticaretteki etkinliğimizin yakın coğrafyamızın ötesine taşınmasına yönelik çabalarımızda Afrika kıtasının özel bir önemi bulunmaktadır. Zengin doğa ve insan kaynaklarına sahip Afrika kıtasının 21. yüzyılda gelişen yeni bir aktör olarak önemini artırması ve küresel olarak daha etkin bir rol oynaması beklenmektedir (www.mfa.gov.tr/2016).

"Uzun yıllardan beri pasif bir dış politika izleyen Türkiye, yakın ve uzak birçok komşusunu ihmal etmiştir. Afrika, Türk Dış politikasında en çok ihmal edilen bölgelerin başında gelmektedir. Afrika ülkeleri ile ilişkileri geliştirmek, uzun yıllar dış politika öncelikleri arasında yer almamıştır. Bu anlayışın bir sonucu olarak, 1998 yılında 'Afrika'ya Açılım Eylem Planı'nın ve 2003 yılında 'Afrika Ülkeleriyle Ekonomik İlişkilerin Geliştirilmesi Stratejisi'nin kabulüne kadar Afrika ülkelerine ilişkin sistematik bir dış politikanın varlığından söz etmek mümkün değildir. Ancak, uzun yıllar minimum düzeyde seyreden Türkiye-Afrika ilişkileri, özellikle 2005 yılının 'Afrika yılı' ilan edilmesinin ardından gelişmeye başlamıştır". "Afrika ülkeleriyle ticari ilişkilerin arttırılması isteği, Türkiye'nin uluslararası politikada etkin olma çabası ile yakından ilgili olarak diş politikada ihmal edilen ülkelerle ilişkilerin geliştirilmesi ve büyük güçlerin kıtaya artan ilgisi şeklinde özetlenebilir. Afrika ülkeleri ile ilişkileri sürdürürken geçmişte yapılan ihmalin tekrar edilmemesi önemli bir gelişmedir. Ancak, Afrika ülkelerine karşı izlenecek dış politikada tutarlı ve sistematik olunması, gerek ikili gerekse çok taraflı ilişkilerin geleceği açısından oldukça büyük önem arz etmektedir"(www.mfa.gov.tr). 
“Sahra Altı Afrika (SAA) ülkeleriyle son yıllarda gelişen ilişkilerimiz Türk dış politikası için bir başarı öyküsüdür. Afrika'ya Açılım Politikası sürecinde bölge ülkeleriyle siyasi ilişkilerden ticaret, yatırımlar ve kalkınma işbirliğine kadar her alanda önemli ilerleme sağlanmıştır". “Türkiye'nin resmi kalkınma yardımlarının yaklaşık üçte birini Afrika ülkelerine yapılan yardımlar oluşturmaktadır. Ülkemizce Sahra Altı Afrika'ya 2014 yılında 383 milyon Dolar kalkınma yardımı yapılmıştır". Türkiye'nin Afrika'ya yönelik ilgisinin altında yatan bir neden, kıta ülkeleriyle ticari ilişkileri geliştirme isteğidir. Diğer neden ise uluslararası politikada etkin olma çabasıyla ilgilidir (Eyrice, 2015).

“Sonuç olarak; Türkiye'nin Afrika ülkeleriyle ilişkilerini güçlendirdiğini, Afrika ülkeleriyle siyasi, ekonomik ve diplomatik ilişkilerini geliştirdiğini; eğitim, sağlık ve kültür alanındaki işbirliği faaliyetleriyle halklar arasındaki bağları da kuvvetlendirdiği söylenebilir.

Türkiye, Afrika'da 16 ülke ile turizm anlaşması imzalamıştır. Bu ülkelerin bir kısmı orta gelişmiş düzeyindeki ülkelerdir ve Türkiye ile geçmiş ortak tarih ve kültürel geçmişe sahiptir. Ancak Sahra Altı Afrika'daki Etiyopya, Gabon, Gana ve Sudan fakir ülkelerdir ve bu ülkeler ile de Türkiye "Turizm İşbirliği Anlaşması" imzalamıştır. Tablo 1'de Türkiye'nin Afrika'daki ülkelerle yaptığı Turizm İşbirliği Anlaşmaları yer almaktadır.

Tablo 1: Türkiye'nin Afrika'da Turizm Anlaşması İmzaladığı Ülkeler

\begin{tabular}{|l|l|l|l|}
\hline $\begin{array}{l}\text { Sura } \\
\text { No }\end{array}$ & Ülkeler & Anlaşma Tarihi & Resmi Gazete Tarihi/Sayısı \\
\hline 1 & Cezayir & 12 Ocak 1980 & $14.03 .1980 / 16929$ \\
\hline 2 & Etiyopya Cumhuriyeti & 8 Şubat 2007 & $10.03 .2011 / 27870$ \\
\hline 3 & Fas & 27Ağustos 1992 & $23.02 .1993 / 21505$ \\
\hline 4 & Fildişi Sahili & 26 Mart 2015 & $28.08 .2015 / 29459$ \\
\hline 5 & Gabon & 25 Mart 2011 & $11.09 .2012 / 28408$ \\
\hline 6 & Gana Cumhuriyeti & 20 Ekim 2011 & $07.05 .2013 / 28630$ \\
\hline 7 & Gine & 03 Mart 2016 & $30.06 .2016 / 29758$ \\
\hline 8 & $\begin{array}{l}\text { Güney Afrika } \\
\text { Cumhuriyeti }\end{array}$ & 23 Haziran 2000 & $04.11 .2000 / 25015$ \\
\hline 9 & Kenya Cumhuriyeti & 28 Ekim 2010 & $\begin{array}{l}\text { Resmi Gazetede Kaydı } \\
\text { Bulunamadı }\end{array}$ \\
\hline 10 & Kongo Cumhuriyeti & 14 Haziran 2013 & $06.03 .2014 / 28933$ \\
\hline 11 & Mali & 19-20 Haziran 2013 & - \\
\hline 12 & Misır Arap Cumh. & 7 Eylül 2005 & $14.05 .2009 / 27228$ \\
\hline 13 & Nijerya & 2 Şubat 2011 & $\begin{array}{l}\text { Resmi Gazetede kaydı } \\
\text { bulunamamışır }\end{array}$ \\
\hline 14 & Sudan & 19 Aralık 1999 & $10.09 .2000 / 24166$ Mükerrer \\
\hline 15 & Tunus & 28 Eylül 1981 & $16.12 .1981 / 17546$ \\
\hline 16 & Uganda & 01 Haziran 2016 & $02.11 .2016 / 29876$ \\
\hline
\end{tabular}

Kaynak: http://disiliskiler.kulturturizm.gov.tr 
EK 1'de 2011 - 2016 yılları arasında Afrika ülkelerinden ülkemize gelen yabancı ziyaretçi sayıları yer almaktadır.

Türkiye'nin Afrika ülkeleri ile yaptığı turizm anlaşmalarının metinleri incelendiğinde hepsinin benzer nitelikli anlaşmalar olduğu görülür. Genel olarak tüm anlaşmalarda taraflar; turizm ürünlerinin geliştirilmesi ve pazarlanması amacı ile bilgi ve deneyim paylaşımında bulunmayı, ülkelerindeki turizm sektörü temsilcileri için çalışma grupları oluşturmayı, eğitimler ve seminerler organize ederek ve birbirleriyle karşılıklı uzman değişiminde bulunarak teknik bilgi alışverişini gerçekleştirmeyi arzu etmektedir. Anlaşmalar 5 yıllık olup taraflar itiraz etmediği sürece sürekliliği devam edecektir. Anlaşmaların turistik seyahatlere etkisinin incelendiğinde çok fazla etkisinin olmadığı görülmektedir.

Sahra Altı Afrika ülkeleri (Etiyopya, Sudan, Gabon, Gana) fakir ve Türkiye'ye uzak olan ülkelerdir. Turistik talebe etki eden unsurlardan yeterli gelire sahip olma ve gidilecek ülkeye olan mesafenin yakınlığı çok önemli iki olgudur. Etiyopya, Sudan, Gabon ve Gana'dan Türkiye'ye çok az sayıda turist gelmektedir. Afrika ülkelerinden Türkiye'ye gelen turistlerin sayısı bir milyonun altındadır. Tüm yabancı ziyaretçilerin \% 2'si Afrika ülkelerinden gelmektedir.

Sahra Altı ülkelerinden olan Gana ile ilişkiler ve Gana ile yapılan Turizm İşbirliği Anlaşması (2011yılında) araştırma için iyi bir örnektir. Dış İşleri Bakanlığı kaynakları Gana ile ilişkilerimizi şöyle açıklamaktadır: “Gana'nın 1957 yılında bağımsızlığını kazanmasını takiben iki ülke arasında diplomatik ilişki tesis edilmiş ve Başkent Akra'da yerleşik ilk Büyükelçimiz Ekim 1964'de göreve başlamıştır. Tasarruf tedbirleri nedeniyle 1981 yılında faaliyetlerine son verilen Akra Büyükelçiliğimiz 1 Şubat 2010 tarihinde tekrar açılmıştır. Gana, 2012 yılında Ankara'da Büyükelçilik açmıştır. Gana ile ekonomik, teknik, turizm, eğitim, kültür, spor, askeri, terörizm ve benzeri konularda 1997 yılından bu güne kadar 18 anlaşma imzalanmıştır. İmzalanması öngörülen anlaşma sayısı 9'dur".

“Türkiye-Gana ticaret hacmi 2010 yılında 40,7 milyon Dolar iken, 2011 ve 2012 yıllarında 10 kattan fazla artarak yarım milyar Doları aşmıştır. Gana'daki ekonomik gelişmelerin de etkisiyle 2013 (382 milyon Dolar) ve 2014 (291,15 milyon Dolar) yıllarında iki ülke ticaret hacminde azalma olmuştur. Gana'da 44 adet Türk firması tarafından 240 milyon Dolar civarında yatırım yapılmıştır. Ülkemizde ise iki tane Gana sermayeli şirket mevcuttur. THY'nin İstanbul-Akraİstanbul arasında haftada 7 gün doğrudan uçuşları bulunmaktadır" (www.mfa.gov.tr).

Türkiye Cumhuriyeti Hükümeti ile Gana arasında 2011 yılında imzalanan Turizm Anlaşmasının resmi gazetede yayımlanmış metni incelenmiş ve anlaşmada yer alan maddeler (EK: 2) araştırma verileri olarak kullanılmıştır. Gana ile imzalanan "Turizm Alanında İşbirliği Anlaşması" da yukarda genel hatlarıyla verdiğimiz anlaşma maddelerine benzemektedir. Anlaşmaya genel hatlarıyla bakıldığında şu konuların yer aldığı görülmektedir:

- Karşılıklı fayda ve eşitlik temelinde turizm alanında işbirliği yapılacağı ve geliştirileceği,

- Turist trafiğini arttırmak için seyahat/vize işlemlerinin kolaylaştırılacağı,

- Turizmle ilgili bütün alanlarda düzenli değişim programı uygulanacağı,

- Turizm eğitimi, teknik yardım, eğitim gezisi ve teknik yardım konularında işbirliği,

- Turizm endüstrisi alanında diğer ülkenin turizm altyapısı, kapasite ve diğer turizm yatırımlarının destekleneceği, 
- Sürdürülebilir turizm gelişimi ile eko-turizm, gençlik turizmi, inanç turizmi, kültür turizmi vb. konularda işbirliği yapılacağı, ifade edilmiştir.

- Ayrıca, turistlere sunulacak hizmetler çerçevesinde; can ve mal güvenliğinin sigortalanması ve konaklama tesislerinde belirtilen kalitede hizmet verilmesini temin için denetleme yapılacağı da anlaşma maddelerinde yer almıştır.

Gana ile imzalanan 6381 sayılı "Türkiye Cumhuriyeti Hükümeti ile Gana Cumhuriyeti Hükümeti Arasında Turizm Alanında İşbirliği Anlaşması" Kanunu'nun Gerekçesinde şu konular yer almıştır: “Turizm alanında iş birliği, ülkeler arasında köklü ve sağlam ilişkiler kurulmasına; farklı toplumlar arasında etkileşim ortamı yaratılmasına; ekonomik, ticari ve siyasi ilişkilerin geliştirilmesine uygun bir zemin hazırlamaktadır. Ayrıca bu alandaki iş birliği, ülkeler arasındaki ilişkiyi orta ve uzun vadede sağlam bir zemine oturtması bakımından da son derece önemlidir. Ülkelerin yaşamakta olduğu siyasi, ekonomik ve teknolojik gelişmeler ve tüm bu alanlardaki küreselleşme eğilimi; turizmi, sınır tanımayan bir konu olarak dünya gündeminin öncelikli konuları arasına yerleştirmiştir. Bu sebeple ülkemizin Afrika'ya açılım politikası çerçevesinde, "Türkiye Cumhuriyeti Hükümeti ile Gana Cumhuriyeti Hükümeti Arasında Turizm Alanında İşbirliği Anlaşması" 20 Ekim 2011 tarihinde Akra'da imzalanmıştır. Söz konusu Anlaşma ile taraflar karşılıklı fayda ve eşitlik temeline dayanarak ilgili kanunları çerçevesinde turizm alanında iş birliğini teşvik etmeyi, geliştirmeyi amaçlamaktadırlar. Ayrıca iki ülkenin turizm sektörleri arasında güçlü bir bağlantı kurulması, tecrübe paylaşımı gerçekleştirilmesi ve turizm alanında eğitimin teşvik edilerek ülkelerin kültürel, siyasi ve ekonomik alanlardaki gelişimi desteklenecektir" (www.tbmm.gov.tr). Turizmin dış politika açısından önemi Gana ile imzalanan anlaşmanın gerekçesinde çok net biçimde ortaya konmuştur.

\section{SONUÇ ve ÖNERILLER}

Türkiye, Afrika'da uzun vadeli bir dış politika izlemekte ve Afrika'daki birçok ülke ile ilişkileri geliştirmektedir. Bu ülkelerden biri de Gana'dır. Gana ile ekonomik, teknik, turizm, eğitim, kültür, spor, askeri, terörizm ve benzeri konularda birçok anlaşma imzalanmıştır. Turizm alanında Türkiye Cumhuriyeti Hükümeti ile Gana ile imzalanan anlaşmada şu konulara yer verilmiştir:

Türkiye Cumhuriyeti ile Gana arasında turizm alanında imzalanan anlaşmanın temel amacının iki taraf arasındaki uluslararası turistik faaliyetleri arttırmak olduğu ifade edildikten sonra bu çerçevede gerçekleştirilmesi gereken hukuki ve idari düzenlemeler yer almıştır. Bunlar arasında; vize muafiyetlerinin sağlanması, turizm alanında karşılıklı tecrübe paylaşımı ve alt ve üst yapı yatırımlarının teşvik edilmesi, önem arz eden konular arasındadır. Ayrıca, turizm faaliyetlerinin; sürdürülebilir turizm, eko-turizm, kongre turizmi gibi çeşitlendirilmesini de kapsamaktadir.

Afrika Sahra Altındaki fakir ülkelerle yapılan turizm anlaşmalarının bu ülkelerden Türkiye'ye gelen turist talebine etkili olmadığ 1 söylenebilir. Turistik talebi; ekonomik, sosyal, politik, kültürel, dini vb. faktörler etkilemektedir. Ancak talebin gerçekleşmesi için; yeterli düzeyde gelir ile birlikte turistik destinasyonun uzaklığı ve yakınlığı çok önemlidir. Türkiye'nin turizm işbirliği anlaşması imzaladığı Sahra Altı Afrika Ülkeleri (Etiyopya, Gabon, Sudan, Gana) hem dünyanın en fakir ülkeleri arasındadır, hem de Türkiye'ye coğrafi olarak uzak ülkelerdir. 
Türkiye Cumhuriyeti Hükümetlerinin; Afrika'daki ülkelerle imzaladığı turizm ve diğer konulardaki anlaşmaların, uzun vadede karşılıklı çıkar ilişkisi ve uzun vadeli dış politika stratejisi çerçevesinde, ekonomik, politik, kültürel ilişkileri geliştirme amacıyla imzaladığı anlaşılmaktadır. Bu sonuç; Dış İşleri Bakanlığı'nın açıklamaları ile uyumludur.

Türkiye'nin bulunduğu coğrafyada bir güç olarak yer alması için; yakın ve uzak mesafedeki ülkelerle, özellikle tarihi ilişki içinde olduğu ülkelerle iyi ilişkiler içinde olması, var olan ilişkilerin daha da iyileştirilmesi, Türkiye'nin uzun vadeli politikası açısından son derece önemlidir.

\section{KAYNAKÇA}

Akbaş, Z. ve Tuna, H. (2012). “Bir Dış Politika Aracı Olarak Yumuşak Gücün Turizm Sektörüne Etkisi: Türkiye Örneği Üzerinden Bir Değerlendirme", Finans Politik ve Ekonomik Yorumlar, 49/571:5-17.

Arı, T. ( 2008). Uluslararası İlişkiler ve Dış Politika, 7. Basım, Bursa: Marmara Kitap Merkezi.

Criss, N. B. (2002). Türkiye Cumhuriyetinin Dış Politikaları, Doğu Batı Dergisi, 6(21): 141-158

Gözler, K. (2007). Hukuka Giriş, 4. Basım, Bursa: Ekin Kitap Evi.

Kürkçüoğlu, Ö. (1980). Dış Politika Nedir? Türkiye'deki Dünü ve Bugünü. Ankara Üniversitesi Siyasal Bilgiler Fakültesi Dergisi, 35(1): 309:335.

Eyrice, E. (2015). Afrika'da Ne Arıyoruz? Türk Dış Politikasında Afrika Açılımı, Cilt IV, Sayı 4, s.92-103, Türkiye Politika ve Araştırma Merkezi (Research Turkey), Londra: Research Turkey (http://researchturkey.org/?p=8723\&lang=tr) (Erişim: 01.04.2016)

UNWTO. (2015). Tourism Highlights, 2015 Edition, http://unwto.org/en (Erişim: 30.03.2016)

Usta, Ö. (2014). Turizm, Genel ve Yapısal Yaklaşım, 4. Baskı, Ankara: Detay Yayıncılık.

T.C. Başbakanlık Kamu Diplomasisi Koordinatörlüğü, Açılım perspektifinden stratejik ortaklık politikasına: Türkiye- Afrika ilişkileri http://kdk.gov.tr/haber/acilim-perspektifinden-stratejikortaklik-politikasina-turkiye-afrika-iliskileri/549 (Erişim: 30.03.2016).

http://www.ktbyatirimisletmeler.gov.tr/TR,9854/sinir-giris-cikis-istatistikleri.html, (Erişim:10.07.2017).

http://www.basbakanlik.gov.tr/docs/.../64.hukumet_programi.pdf S.102 (Erişim: 04.04.2016)

http://disiliskiler.kultur.gov.tr/TR,22118/imzalanan-ikili-ve-cok-tarafli-belgeler.html (Erişim: 10.07.2017)

http://www.resmigazete.gov.tr/uluslararası sözleşme default.aspx\# 07.12.2007 tarih ve 26723 sayılı R.G. (Erişim: 25.03.2016)

http://www.tursab.org.tr/tr/seyahat-acentalari/dunden-bugune-seyahat-acentalari_501.html (Erişim: 20.03.2016)

http://www.mfa.gov.tr/dis-politika-genel.tr.mfa (Erişim: 04.04.2016)

http://www.mfa.gov.tr/turkiye_nin-ortadogu-ile-iliskileri.tr.mfa (Erişim: 04.04.2016) 
http://www.mfa.gov.tr/site_media/html/2016-yili-basinda-dis-politikamiz.pdf

(Erişim: 04.04.2016)

http://www.mfa.gov.tr/turkiye-gana-siyasi-iliskileri.tr.mfa (Erişim: 12.04.2016) 
EK:1 2011-2016 Yıllarında Türkiye'ye Afrika Ülkelerinden Gelen Yabancı Ziyaretçiler*

\begin{tabular}{|c|c|c|c|c|c|c|}
\hline \multirow{2}{*}{ Milliyet } & \multicolumn{6}{|c|}{ YILLAR } \\
\hline & 2011 & 2012 & 2013 & 2014 & 2015 & 2016 \\
\hline Angola & 796 & 857 & 1458 & 2526 & 2019 & 1404 \\
\hline Batı Sahara & - & - & - & - & - & - \\
\hline Benin & 288 & 339 & 1577 & 714 & 818 & 779 \\
\hline Bostvana & 102 & 202 & 168 & 629 & 188 & 167 \\
\hline Burkina Faso & 506 & 621 & 1563 & 2120 & 2389 & 1676 \\
\hline Burundi & 119 & 178 & 251 & 265 & 268 & 282 \\
\hline Cezayir & 84844 & 104489 & 118189 & 160052 & 171873 & 176233 \\
\hline Cibuti & 186 & 281 & 646 & 916 & 1199 & 1463 \\
\hline Çad & 150 & 147 & 417 & 979 & 925 & 1010 \\
\hline $\begin{array}{l}\text { Demokratik Kongo } \\
\text { Cumhu. }\end{array}$ & 11 & 327 & 4312 & 6026 & 5979 & 5179 \\
\hline Ekvator Ginesi & 57 & 44 & 69 & 130 & 117 & 133 \\
\hline Eritre & 382 & 546 & 584 & 1237 & 1608 & 1447 \\
\hline Etiyopya & 1912 & 2826 & 3488 & 4480 & 5095 & 5408 \\
\hline Fas & 68645 & 77884 & 82579 & 89562 & 109775 & 87660 \\
\hline Fildişi Sahili & 1280 & 1847 & 2407 & 6373 & 2957 & 2807 \\
\hline Gabon & 268 & 473 & 1902 & 1691 & 2259 & 1577 \\
\hline Gambiya & 350 & 389 & 528 & 633 & 560 & 694 \\
\hline Gana & 1817 & 3597 & 5225 & 4093 & 3765 & 3309 \\
\hline Gine & 645 & 601 & 666 & 710 & 829 & 1041 \\
\hline Gine Bissao & 112 & 135 & 161 & 159 & 172 & 162 \\
\hline Güney Afrika & 34394 & 40771 & 44798 & 43049 & 47679 & 29316 \\
\hline Güney Sudan & & & & & & 194 \\
\hline Kamerun & 1609 & 2411 & 5775 & 6027 & 6198 & 5498 \\
\hline Kenya & 4541 & 5510 & 6226 & 6880 & 7506 & 5986 \\
\hline Komor Adaları & 1020 & 783 & 989 & 1196 & 1210 & 983 \\
\hline Kongo Cumhuriyeti & 3902 & 2847 & 781 & 605 & 837 & 683 \\
\hline Lesoto & 87 & 35 & 49 & 61 & 80 & 76 \\
\hline Liberya & 164 & 167 & 444 & 529 & 455 & 233 \\
\hline Libya & 53562 & 213890 & 264266 & 267501 & 234762 & 72014 \\
\hline Madagaskar & 341 & 837 & 357 & 319 & 326 & 360 \\
\hline Malavi & 159 & 226 & 264 & 220 & 319 & 219 \\
\hline Mali & 834 & 880 & 1439 & 1467 & 2103 & 2149 \\
\hline Mauritus & 3255 & 4088 & 2648 & 4046 & 4078 & 2499 \\
\hline Misir & 79665 & 112025 & 107437 & 108762 & 100040 & 94871 \\
\hline Moritanya & 833 & 1333 & 1600 & 1744 & 1742 & 1742 \\
\hline Mozambik & 311 & 386 & 485 & 586 & 708 & 698 \\
\hline Namibya & 178 & 206 & 253 & 271 & 363 & 314 \\
\hline Nijer & 342 & 510 & 1338 & 1346 & 1268 & 1369 \\
\hline Nijerya & 14564 & 19897 & 22869 & 28387 & 27711 & 25264 \\
\hline $\begin{array}{l}\text { Orta Afrika } \\
\text { Cumhuriyeti }\end{array}$ & 140 & 144 & 172 & 178 & 134 & 177 \\
\hline Ruanda & 188 & 510 & 486 & 593 & 667 & 635 \\
\hline Sao Tome & 19 & 27 & 1023 & 855 & 919 & 162 \\
\hline
\end{tabular}




\begin{tabular}{|l|c|c|c|c|c|c|}
\cline { 1 - 5 } Senegal & 5579 & 5650 & 4811 & 5133 & 5483 & 5705 \\
\hline Seyseller & 80 & 120 & 131 & 206 & 203 & 141 \\
\hline Somali & 1608 & 3501 & 3357 & 3737 & 4502 & 3496 \\
\hline Sudan & $\mathbf{7 4 5 8}$ & $\mathbf{8 1 6 1}$ & $\mathbf{9 3 1 9}$ & $\mathbf{1 0 7 1 4}$ & $\mathbf{1 1 4 3 4}$ & $\mathbf{1 0 5 6 2}$ \\
\hline Svaziland & 43 & 68 & 103 & 86 & 240 & 88 \\
\hline Tanzanya & $\mathbf{2 2 4 7}$ & $\mathbf{2 4 7 6}$ & $\mathbf{3 0 4 8}$ & $\mathbf{3 4 3 9}$ & $\mathbf{3 3 0 9}$ & $\mathbf{2 3 1 2}$ \\
\hline Togo & 258 & 314 & 463 & 420 & 460 & 401 \\
\hline Tunus & $\mathbf{6 3 1 7 6}$ & $\mathbf{8 6 5 9 5}$ & $\mathbf{9 1 6 8 3}$ & $\mathbf{1 0 0 6 1 2}$ & $\mathbf{1 0 2} \mathbf{3 4 1}$ & $\mathbf{1 0 0 1 8 5}$ \\
\hline Uganda & $\mathbf{1 4 4 5}$ & $\mathbf{1 8 9 5}$ & $\mathbf{2 9 1 4}$ & $\mathbf{3 4 1 9}$ & $\mathbf{2 9 8 0}$ & $\mathbf{3 0 4 4}$ \\
\hline Yeşil Burun Adalar1 & 84 & 128 & 88 & 145 & 131 & 77 \\
\hline Zambiya & 339 & 457 & 683 & 787 & 883 & 809 \\
\hline Zimbabve & 379 & 515 & 753 & 1174 & 1678 & 1699 \\
\hline
\end{tabular}

Kaynak: http://www.ktbyatirimisletmeler.gov.tr/TR,9854/sinir-giris-cikis-istatistikleri.html (10 Temmuz 2017)

NOT: Turizm Anlaşması imzalanan ülkeler koyu olarak gösterilmiştir.

* Yabancı (Uluslararası) Ziyaretçi: Daimi ikametgâhı ve yaşadığı çevrenin dışındaki bir ülkeyi, 12 ayı aşmayan süreyle ve o ülkede para karşılığı bir iş yapmak dışında bir amaçla ziyaret eden kişidir. 


\section{EK: 2 TÜRKIYYE CUMHURIYETİ HÜKÜMETI İLE GANA CUMHURIYYTİ HÜKÜMETI ARASINDA TURIZM ALANINDA İ̧̧BİRLIĞİ ANLAŞMASI}

Türkiye Cumhuriyeti Hükümeti ile Gana Cumhuriyeti Hükümeti (bundan böyle "taraflar" olarak anılacaktır), Bundan böyle, var olan dostluk ilişkilerini güçlendirmeyi arzulayarak, Aşağıdaki hususlarda mutabakata varmışlardır;

\section{Madde 1: İşbirliğinin Kapsamı}

Taraflar karşılıklı fayda ve eşitlik temelinde ilgili kanunları çerçevesinde turizm alanında işbirliğini teşvik edecekler, geliştirecek ve artıracaklardır.

\section{Madde 2: Giriş Formaliteleri ve İşlemleri}

Taraflar, iki ülke arasındaki turist trafiğini daha da artırmak için, seyahat/vize işlemlerini, kendi ulusal yasalarına uygun olarak kolaylaştıracaklardır.

\section{Madde 3: Değiş̧im Programları}

1) Taraflar, turizmle ilgili bütün alanlarda düzenli değişim programları düzenlenmesini kolaylaştıracak ve destekleyeceklerdir.

2) Taraflar, turizm eğitimi, teknik yardım, eğitim gezisi ve turizm uzmanları değişimi aracılığıyla değişim programlarında işbirliği yapacaklardır. Yapılacak değişimler tarafların belirleyeceği esaslar çerçevesinde gerçekleştirilecektir.

\section{Madde 4: Yatırım}

Taraflar kendi ülkelerinde geçerli olan yerel kanunlara göre, diğer ülkenin turizm endüstrisi alanında aşağıdaki konularda karşılıklı yatırımı destekleyeceklerdir.

a) Turizm altyapisı ve kalkınması

b) Kapasite oluşturulması

c) Taraflar tarafından kabul edilecek diğer turizm yatırım çeşitleri

\section{Madde 5: Çevresel Yükümlülükler}

Taraflar sürdürülebilir turizm gelişimi ile eko-turizm, gençlik turizmi, kültür turizmi, inanç turizmi vb. turizm çeşitlerinin tanıtımı için işbirliği yapacaklardır.

\section{Madde 6: Turizm Güvencesi ve Güvenliği}

Türkiye Cumhuriyeti Hükümeti ile Gana Cumhuriyeti Hükümeti turistik amaçlı seyahat eden karşılıklı vatandaşlarının güvenliğini sağlamak için;

1) Taraflar, kendi ülkelerinin turizm organizasyonlarına, turistlerin sağlığını ve hayatını tehlikeye atabilecek gezileri de içine alan çeşitli riskler, ani hastalıklar ve talihsiz olayların oluşması ihtimaline dayalı olarak uluslararası yüksek standartlara uygun nitelikte; turistlere sunulacak hizmetlerin, can ve mal güvenliklerinin sigortalanmasını teminen bilgilendirilmeleri ve sigortalanmaları konusunda yardımcı olmalarını tavsiye eder.

2) Taraflar, konaklama tesislerinin ilan ettikleri sınıfta ve standartta hizmet vermelerini sağlayacak şekilde denetim yapacaklar ve yoğun sezonda konaklama tesislerinde hizmet kalitesini koruyacak her türlü önlemleri alacaklardır.

\section{Madde 7: Var olan Yükümlülükler}


İşbu Anlaşma, bu Anlaşmadan önce Taraflarca imzalanmış diğer uluslararası turizm anlaşmalarından, sözleşmelerinden ve antlaşmalarından doğan yükümlülüklerin yürütülmesini etkilemeyecektir.

\section{Madde 8: Değişiklik}

İşbu Anlaşma, Tarafların karşılıklı rızası ile diplomatik kanallarla nota değişiminde bulunmaları yoluyla değiştirilebilir. Yapılacak bu değişiklikler İşbu Anlaşmanın 9. Maddesindeki hüküm uyarınca yürürlüğe girer.

\section{Madde 9: Yürürlüğe Girme}

İşbu Anlaşma, her iki Tarafça da iç yasal prosedürlerin tamamlandığına ilişkin birbirlerine diplomatik kanallardan yapılan son bildirimin alındığı tarihte yürürlüğe girecektir.

\section{Madde 10: Geçerlilik ve Süre}

İşbu Anlaşma, beş (5) yıllık süreyle yürürlükte kalacak ve Taraflardan biri süre bitiminden altı ay önce Anlaşmayı feshetme niyetini diplomatik kanallar vasıtasıyla yazılı olarak diğer tarafa bildirmedikçe müteakip eşit dönemler için otomatik olarak yenilenmiş olacaktır.

\section{Madde 11: Sonuç}

İşbu Anlaşma, Taraflardan birinin diğerine altı (6) ay önce diplomatik kanallar vasıtasıyla bildirimde bulunması halinde feshedilebilir.

YUKARIDAKI HUSUSLAR MUVACEHESINDDE, aşağıda imzası bulunanlar hükümetleri tarafından usulüne uygun şekilde yetkilendirilmiş olarak işbu Anlaşmayı imzalamışlardır. İşbu Anlaşma, 20 Ekim 2011 tarihinde Akra şehrinde iki asıl nüsha halinde İngilizce ve Türkçe dillerinde iki metin de eşit derecede geçerli olmak üzere akdedilmiştir. Yorumunda farklılık olması halinde, İngilizce metin esas alınacaktır.

Türkiye Cumhuriyeti

Hükümeti Adına

Prof. Dr. Recep Akdağ

Sağlık Bakanı
Gana Cumhuriyeti

Hükümeti Adına

Akua Sena Dansua

Turizm Bakanı

Kaynak: 07.05.2013 tarih ve 28640 sayılı Resmi Gazete 